\title{
Manifestations of Bad Governance on the Threshold of African Democratic Process and Development
}

\author{
Essien D. Essien \\ Department of Religious and Cultural Studies, \\ Faculty of Arts, \\ University of Uyo \\ Uyo, Akwa Ibom State, \\ Nigeria \\ Email: essienpecus@yahoo.com \\ DOI:http://dx.doi.org/10.4314/gjds.vgi2.2
}

\begin{abstract}
This paper argues that there is a worldwide resurgence of interests on the concept of good governance, democracy and development. This is because everything in the world today revolves around development. The current framework of public policy imperatives that emanate from around the world suggests that effective entrenchment of democracy and good governance is a prerequisite for development. This paper examines the challenges of good democratic governance in Africa in contemporary time. This orbits around the problems of bad governance which manifests is corruption and other forms of particularistic behaviour through the noninstitutionalisation of accountability institutions and mechanisms. It argues that the absence of effective measures to counter these perennial "demons" could result in stagnation, lack of growth and development. The paper concludes that improving governance requires effective democratic process driven by ethical principles which would regulate how people make right decisions about governance.
\end{abstract}

KEY WORDS: Africa, Governance, Democratization, Good governance, Development, African development.

\section{Introduction}

Despite the significant advances in human development in recent times, the search for aptness in government and governance that is oriented toward development, the common good and wellbeing of the people of Africa has become something of a scandal and simply ironic (Anyanwu, 1998:148). The ubiquity of the governance phenomenon in contemporary times has made most African and indeed, global multilateral organizations, 
like the world Bank, United Nations Development Programme (UNDP), and the United Nations Economic Commission for Africa (UNECA) to become "governance infatuated" by giving prescription and insisting that governance reform is the key to economic growth and development in Africa. This situation presents two contrasting and complementary reasons to provoke our moral thought why we should show concern and invoke ethics, values and norms of good governance which would enable us to raise evaluative questions about proper procedures, transparency, the quality and process of decision making, selection of officials and other such matters (Doornbos, 2001:94). First is the abhorrence of the state of agreed indicators regarding high poverty level, unavailability of safe drinking water supply, high infant mortality rate, high literacy rate, absence of electrification, high percentage of girls married below 18 years, and high percentage of villages not connected by road. These pointers constitute factors undermining growth and development. Second is the fact that the prevalence of corruption and mal-administration has become less and less loathed, but rather more and more a business with governance actors like the leaders and representatives not visualizing ethical responsibility which threatens good governance, growth and development.

This clearly manifests itself in the prevalence of a number of corruption fighting institutions in Africa as well as the government officials either prosecuted and/or convicted for corruption and corruption related offences. In addition is the case of poor budgetary practices and implementation which has impeded the promotion of responsive governance, social stability and social inclusiveness in governance. However, the need for development occupies a primary place in the lives of individuals, groups, nations and states. The desire has always been for people to move closer toward development instead of encountering impediments that keeps them away from it. Perhaps the most intriguing aspect of the situation is that in the last few decades, various ideas, concepts, issues and agendas of many institutions have been developed on how to achieve good governance and development and thus stem the tide of the declining fate and fortune of many countries especially in Africa (Abrahamsen 2000:133-134). This has lends credence to the fact that governance has come to mean different things to different people. While some view it as the act of governing, others draw a corollary between it and the democratization process, the process of empowering the civil society actors and institutions, and some others view it in a more nuanced form as the awkward relationship between the state and civil society (UNDP, 1997:19-20).

The point that is apparent here is that development is about human beings and is evaluative in nature. It is against this backdrop that information derived from content analysis of secondary data set the stage for the study. The study however, adopted descriptive research method which seeks to find out the conditions and relationships of the subject that exist, opinions that are held, processes that are going on, effects that are evident, or/and trends that are developing about governance in Africa. The observation of the paper is that the drive toward good governance in Africa needs to be translated into some quantifiable index for the common good. The present scenario where the impact 
of good governance in some part of contemporary Africa is in its paucity has resulted in numerous perverse manifestations detrimental to sustainable growth and development.

\section{Conceptual Clarification}

The concepts of governance, democratization, good governance and development have for some time now stimulated increasing international dialogue; and a considerable amount of scholarship has evolved from it. In spite of the rising interest in these subjects, there still exists a wide stretch of uncertainty about their meanings and relationships. The conceptual indecisiveness, as well as the mystifications that hang around these concepts could be credited to the fact that, all seems to be, though in varying degrees, multidimensional and value loaded concepts.

\section{Governance}

The question of governance has emerged as a key concept pre-occupying the considerations of all societies. It is a multilevel and broad concept that operates at every level of the social order, such as household, village, municipality, nation, region or globe. But the challenge for all societies today is to create a system of governance that promotes, supports and sustains human development, especially for the poorest and most marginal. In the light of this logic, the search for a clearly articulated concept of governance has presented a more serious dilemma to human existence around the world. It is pertinent to avow that early discussions on this subject goes back to at least 400 B.C. during which Arthashastra, a fascinating treatise on governance was attributed to Kautilya, thought to be the chief minister to the King of India (Kaufmann, 2001: 99). In it, Kautilya presented key pillars of the 'art of governance', emphasizing justice, ethics, and anti-autocratic tendencies. He further detailed the duty of the king to protect the wealth of the State and its subjects; to enhance, maintain and also safeguard such wealth, as well as the interests of the subjects.

Notwithstanding the long provenance of the concept of governance, there is as yet no strong consensus around a single definition of the term governance. Let us now attempt a definition of the term, governance. From a detached perspective, governance can be viewed as the background through which institutions by which authority in a given country is exercised for the common good. This includes the process which those in authority are selected, monitored and replaced, as well as the capacity of the government to effectively manage its resources and implement sound policies (World World Bank, 2006: 37). Furthermore, communal governance represents more than a means of providing common good, as it can be related to the government capacity to help their citizens' ability to achieve individual satisfaction and material prosperity. Therefore, governance could be compared to the management, supply, and delivery of political goods to citizens of a nation-state. Political goods in this regard are diverse; they comprise human security, rule of law, political and civil freedoms, medical and health 
care, schools and education, communication networks, money and banking system, fiscal and institutional context, support for civil society, or regulating the sharing of the environmental commons (Besancon 2003: 20). The practice of governance is also ruled by community values, informal traditions, accepted practices, or unwritten codes of conduct (Plumptre 2006: 18).

\section{Democratization}

The idea behind the clamor for democracy all over the world is not inadvertent. Those who go about with such understanding of agitating for democratization are convinced that no society truly desirous of development can ignore democracy. Democratization therefore, basically, connotes a process of movement from authoritarianism to a stable democracy. Some scholars like Osaghae (1999:5), equates democratization with transition to democracy, he argues that democratization involves "a political process because it basically has to do with the transformation of the state and the political society". This idea, obviously, disentangles the economic dimension of democratization. This position derives from the belief that though the economic dimension provides an enabling environment for democratization, they do not form part of its definition. Similarly, democratization has been defined as: a political movement from less accountable to more accountable government, from less competitive (or non-existent) elections to fuller and fairer predicted civil and political rights, from weak (or non-existent) autonomous associations to more numerous associations in civil society (Potter, 2000:368). This definition also neglects the economic dimensions.

Nevertheless, it emphasizes the relevance of good governance in the democratization process as well as other certain forces (political rights, autonomous civil society) that could strengthen the process. If democratization, as suggested by the above definitions, implies the process of getting to a stable or consolidated democracy, the transitional process is no doubt daunting and challenging. Indeed, the process could trigger higher undesirable side effects particularly in collapsed states (Ottaway 1995:235, Huntington, 1996, Ihonvbere, 1997). It is instructive to note that a democratic regime, being the ultimate goal of democratization, operates on certain fundamental principles. It is reasoned that the extent to which democratization establishes these elements may provide the basis for evaluating its success or otherwise. These principles include: (i) Pluralism and multi partyism, including free and fair competitive politics as well as relatively autonomous civil society. (ii) Popular participation in the political process provided those elected remain accountable and can be voted out if they no longer enjoy the people's support. (iii) Rule of law, respect for human rights and equality of access to all citizens and groups to the state power and resources; and (iv) Constitutionalism or respect for the rules of the game, which includes civil control of the military and the efficacy of representative, judicial and oversight institutions (Osaghae, 1999:7). Be that as it may, it should be noted that democratization has generally been seen as the solution to 
Africa's multifaceted problems. The validity of this claim only remains to be supported by empirical realities across the continent.

\section{Good Governance}

The idea of governance as elucidated earlier is said to be "good" when it allocates and manages resources to respond to collective problems, in other words, when a State efficiently provides public goods of necessary quality to its citizens. Hence states should be assessed on both the quality and the quantity of public goods provided to citizens (Rotberg 2004-05). From broad-spectrum, good governance is perceived as a normative principle of public administration and administrative law, which obliges the State, nation or organs of government to perform its functions in a manner that promotes the values of efficiency, non-corruptibility, and responsiveness to civil society (Chowdhury and Skarstedt 2005:12). It is therefore a principle that is largely associated with statecraft. While the government is not obliged to substantively deliver any public goods, it must ensure that the processes for the identification and delivery of such goods are concrete in terms of the followings: (i) being responsive to public demands; (ii) being transparent in the allocation of resources and; (iii) being equitable in the distribution of goods and services. However, the procedure that makes provision for public goods in any society are guided by principles such as human rights, democratization and democracy, transparency, participation and decentralized power sharing, sound public administration, accountability, rule of law, effectiveness, equity, and strategic vision (Cheema 2005 :46). The Human Development Report issued in 2002 insists on "good" governance as a democratic exigency, in order to "free the society of corruption, and give the people the rights, the means, and the capacity to participate in the decisions that affect their lives and to hold their governments accountable for what they do" (Nzongola-Ntalaja 2002: 21). Thus "good" governance promotes gender equality, sustains the environment, enables citizens to exercise personal freedoms, and provides tools to reduce poverty, deprivation, fear, and violence (Cheema 2005 :19). Practically speaking, good governance values required to avert appalling authority entails that actions and policies should translate into the strengthening of democratic institutions especially through the process of free, fair and frequent elections, a representative legislature, and judiciary and media independence.

\section{Development}

The concept of development remains at the forefront of the global political agenda. That is why; all hands are on deck toward making the right to development a reality for everyone in all civilized societies. It is against this backdrop that the heads of the member states of the United Nations proclaimed the Millennium Development Goals at the UN General Assembly in New York (United Nations General Assembly 2000:4). Similar intentions have also been voiced by other bodies like European Union and African Union. 
Development is a multidimensional as well as a value loaded concept (Lane and Ersson, 1997:15-16). As a multidimensional process, development has been viewed differently from political, economic and social dimensions. These various aspects of development are well echoed in the existing studies on the subject matter. For example, Todaro (1985) conceptualizes development as: "a multidimensional process involving major changes in social structures, popular attitudes, and national institutions, as well as the acceleration of economic growth, the reduction of inequality and the eradication of absolute poverty". In another work, the same scholar identified three core values of development (Todaro, 1989:89-90). These include the ability to provide as many people as possible with their basic needs or the ability to acquire adequate food, shelter, health care and protection. It also entail the perception of individuals or groups of self-worth and esteem as a respected member of the society; and freedom in the sense that individuals and society at large have an expanded range of choice, not only with respect to the material necessities for self-reproduction but also in their ability to have a say in, if not to determine, the method and process by which values are allocated in the society (Ogwu, 2002:12-13). It is against this backdrop that a renowned political economist, Armati Sen, offered a more illuminating thought on the concept of development. For him, development connotes 'capacity expansion' and synonymous with freedom (Sen, 1999 :45). As capacity expansion, development requires adequate empowerment of the state and the society such that they can adequately distil their complimentary responsibilities. It requires an enhanced state capacity as well as institutional and governmental stability. It is only within such framework that individual members of the society can find fulfillment in terms of the basic necessities of life. As freedom, development demands great latitude of autonomy for the political community and its constituent parts; as well as for the individual members of such communities.

\section{The Hazards of Bad Governance in Africa}

It will be adequate to point out that a recurring decimal in Africa's development dilemma is the issue of governance. The danger of bad governance looms large in Africa and afflicts a broad spectrum of political regimes be it "parliamentary", "military", "one party" or the much touted multi-party regimes. Fundamentally, the question of good and bad in governance is the subject matter of ethics. According to Madhav (2007) good governance has much to do with the ethical grounding of governance and must be evaluated with reference to specific norms and objectives as may be laid down. It looks at the functioning of the given segment of the society from the point of view of its acknowledged stakeholders, beneficiaries and customers. The society must have firm standing on certain cultural and moral values and principles.

The question dealing with governance, though significantly related to democracy, is culture specific and system bound. It depends to a large extent on the historical experiences of a nation, its cultural mores, the societal values and aspiration of the people, individual and group preferences, current issues, the expectations of the governed, the 
nature and type of the political system, the ideological and religious predisposition of the country and a host of others. The absence of bad governance portends that the material resources of the nation are harnessed and distributed as best as possible to serve the common good; that the economic system is not operated in such a manner as to permit the concentration of wealth or the means of production and exchange in the hands of few individuals or of a select group; and that suitable and adequate shelter, suitable and adequate food, reasonable national minimum living wage, old age care and pensions, and unemployment, sick benefits and welfare of the disabled are provided for all citizens.

Fundamentally therefore, to describe governance as a good one and to determine whether it is a bad one requires the understanding of the essence of the state which are not only embedded in the constitution but also a function of the ethical and religious ideals and the nature of current problems confronting the state. The curious question however is: what went wrong in the governance realm in Africa? Two factors seem to have facilitated bad governance in Africa. First is obviously the colonial pedigree. There is a strong linkage between the absence of good governance in the colonial era and that of the postcolonial period. The political structures and values, economic base and social orientation promoted in the colonial era were antithetical to the evolution of good governance and democracy in Africa (Ekeh, 1975: 94). These structures and processes, firmly implanted, took new manifestations as experienced in maladministration and bad governance, both internal and external in the post-colonial and the neo-colonial era.

Explicitly designed, in the post-colonial period, the emphasis of the political rulers in Africa was on supposedly national integration, unity and development. Thus the dominant doctrine was one of a "dictatorship of development", rather than the "democracy of development". However, given the atomistic nature of some African states, and the subsequent paucity of resources of the ruling class and its lack of complete domination, the tendency was that governance degenerated considerably, as the state became an arena of senseless struggles for accumulation and power control (Lukham, 1994). The net effect was that political alienation and non-involvement of political opponents resulted in increasing material poverty thus undue vulnerability and deprivations became the norms of political governance in Africa. It became apparent that both democracy and good governance consequently withdrew from Africa.

Evidently, Africa's underdevelopment resulting from bad governance is devastating and deep rooted, when compared with that of other parts of the world. For example, Africa is the only region in the world where for some three decades economic growth barely kept ahead of population growth, where the debt burden estimated at US\$300 billion in 1995 is greater than total economic output and equals about 300\% of Africa's export of goods and services, where about 50\% in almost half of the countries live below the poverty line, while illiteracy rate is about 60\%, infant mortality is 96 per 1000, and life expectancy at birth is 52 years (Conable, 1991; World Bank, 1995). In addition, Africa with a 1oth of the world's population was estimated to have a third of the world refugees in 1990 (Degefe, 1990: 187), 
a figure which certainly has increased quite significantly since then, given the internecine civil wars and conflicts in many African countries in recent times.

Fundamental to the challenge of Africa's development problems is a crisis of good governance. This is because the countervailing power has been lacking, therefore, state officials in many Africa countries have chosen only to serve their own interest without fear of being called to account. In self-defense, individuals have built up personal networks of influence, connections and bulwarks rather than hold the all-powerful state accountable for its systemic failure. In this way, politics becomes personalized and patronage becomes essential to maintain power. Germane to the conception of good governance by the World Bank are the issues of public accountability of government officials, transparency in government procedures, rule of law and public sector management (Olukoshi, 1992; Nunnekamp, 1995). The process of evolving good governance in Africa according to the Bank requires the shrinking of the state and engendering support for non-state actors (Civil Society). This is because governance encompasses the state, but it transcends the state by including the private and civil societies.

Table 1: 2011 Governance Performance Index for African Countries (Ranking)

\begin{tabular}{|l|l|l|l|l|l|}
\hline Position & Country & $\begin{array}{l}\text { Score in } \\
\text { Percentage }\end{array}$ & Position & Country & $\begin{array}{l}\text { Score in } \\
\text { Percentage }\end{array}$ \\
\hline $1^{\text {st }}$ & Mauritius & $82 \%$ & $38^{\text {th }}$ & Cameroon & $45 \%$ \\
\hline $2^{\text {nd }}$ & Cape Verde & $79 \%$ & $39^{\text {th }}$ & Niger & $44 \%$ \\
\hline $3^{\text {rd }}$ & Botswana & $76 \%$ & $40^{\text {th }}$ & Congo & $42 \%$ \\
\hline $4^{\text {th }}$ & Seychelles & $73 \%$ & $41^{\text {st }}$ & Nigeria & $41 \%$ \\
\hline $5^{\text {th }}$ & South Africa & $71 \%$ & $42^{\text {nd }}$ & Angola & $41 \%$ \\
\hline $6^{\text {th }}$ & Namibia & $70 \%$ & $43^{\text {rd }}$ & Guinea & $38 \%$ \\
\hline $7^{\text {th }}$ & Ghana & $66 \%$ & $44^{\text {th }}$ & Guinea-Bissau & $37 \%$ \\
\hline $8^{\text {th }}$ & Lesotho & $63 \%$ & $45^{\text {th }}$ & Equatorial Guinea & $37 \%$ \\
\hline $9^{\text {th }}$ & Tunisia & $62 \%$ & $46^{\text {th }}$ & Côte d'Ivoire & $36 \%$ \\
\hline $10^{\text {th }}$ & Egypt & $61 \%$ & $47^{\text {th }}$ & Eritrea & $35 \%$ \\
\hline $11^{\text {th }}$ & Benin & $60 \%$ & $48^{\text {th }}$ & Sudan & $33 \%$ \\
\hline $12^{\text {th }}$ & $\begin{array}{l}\text { São Tomé and } \\
\text { Príncipe }\end{array}$ & $58 \%$ & $49^{\text {th }}$ & $\begin{array}{l}\text { Central African } \\
\text { Republic }\end{array}$ & $33 \%$ \\
\hline $13^{\text {th }}$ & Tanzania & $58 \%$ & $50^{\text {th }}$ & $\begin{array}{l}\text { Congo, Democratic } \\
\text { Republic }\end{array}$ & $32 \%$ \\
\hline $14^{\text {th }}$ & Morocco & $58 \%$ & $51^{\text {st }}$ & Zimbabwe & $31 \%$ \\
\hline
\end{tabular}


Essien D. Essien

Manifestations of Bad Governance on the Threshold of African Democratic Process and Development

\begin{tabular}{|c|c|c|c|c|c|}
\hline Position & Country & $\begin{array}{l}\text { Score in } \\
\text { Percentage }\end{array}$ & Position & Country & $\begin{array}{l}\text { Score in } \\
\text { Percentage }\end{array}$ \\
\hline $15^{\text {th }}$ & Senegal & $57 \%$ & $52^{\text {nd }}$ & Chad & $31 \%$ \\
\hline $16^{\text {th }}$ & Zambia & $57 \%$ & $53^{\text {rd }}$ & Somalia & $8 \%$ \\
\hline $17^{\text {th }}$ & Malawi & $57 \%$ & & & \\
\hline $18^{\text {th }}$ & Algeria & $55 \%$ & & & \\
\hline $19^{\text {th }}$ & Burkina Faso & $55 \%$ & & & \\
\hline $20^{\text {th }}$ & Uganda & $55 \%$ & & & \\
\hline $21^{\mathrm{st}}$ & Mozambique & $55 \%$ & & & \\
\hline $22^{\text {nd }}$ & Mali & $54 \%$ & & & \\
\hline $23^{\mathrm{rd}}$ & Kenya & $53 \%$ & & & \\
\hline $24^{\text {th }}$ & Gambia & $52 \%$ & & & \\
\hline $25^{\text {th }}$ & Rwanda & $52 \%$ & & & \\
\hline $26^{\text {th }}$ & Swaziland & $51 \%$ & & & \\
\hline $27^{\text {th }}$ & Gabon & $51 \%$ & & & \\
\hline $28^{\text {th }}$ & Libya & $50 \%$ & & & \\
\hline $29^{\text {th }}$ & Djibouti & $49 \%$ & & & \\
\hline $30^{\text {th }}$ & Sierra Leone & $48 \%$ & & & \\
\hline $31^{\text {st }}$ & Comoros & $47 \%$ & & & \\
\hline $32^{\text {nd }}$ & Mauritania & $47 \%$ & & & \\
\hline $33^{\text {rd }}$ & Madagascar & $47 \%$ & & & \\
\hline $34^{\text {th }}$ & Ethiopia & $46 \%$ & & & \\
\hline $35^{\text {th }}$ & Togo & $46 \%$ & & & \\
\hline $36^{\text {th }}$ & Liberia & $45 \%$ & & & \\
\hline $37^{\text {th }}$ & Burundi & $45 \%$ & & & \\
\hline
\end{tabular}

Source: Ibrahim Index for African Governance 


\section{Status of Democracy and Good Governance in Africa}

Democracy has been recognized everywhere as the only moral and legitimate way through which a society can be administered. The democratization task is thus, considered as the era of development that every society should strive to attain rather than cling to political preferences (Owolabi, 2001). The issue in contemporary political arena today is not which political system is appropriate but rather when will a particular society become democratized. Consequently, researchers and international financial institutions like the World Bank have established an inextricable connection between democracy and good governance. Interestingly, bad governance is the absence of good governance and may not necessarily mean the absence of democracy. This is evident in the inability of a state to achieve or realize the essence of the state at a particular time. Also bad governance by entailing corruption, and lack of accountability and transparency, provides opportunities for the well - connected elites and interest groups in the society to corner for themselves a sizeable proportion of the society's resources at the expense of the masses (Obadan, 1998). Thus, bad governance is a disagreement with any nation's quest for socio-economic and political development. Therefore, resources of the state must be managed in such a manner as to achieve the desired level of socio-economic progress for all members of the political community.

It is important to note that the resource utilized must also be commensurate with the level of development attained. In short, good governance is about the performance capacity of a government or as it relates to leadership capability. Failure of governance therefore, could expressly mean failure of leadership. Governance is good provided it is able to achieve the desired end of the state defined in terms of justice, equity, protection of life and property, enhanced participation, preservation of the rule of law and improved living standard of the populace. Governance is termed bad when it fails to achieve the purpose(s) of the state. The convergence of opinions about democracy, good governance and development in Africa as is currently practiced has produced indigestible outcome. The consequences of unaccountable governance in Africa have been severe. As documented by Human Rights Watch (HRW), human rights abuses remain pervasive in Africa (HRW, 2002; 2003; 2006). Injustices of all dimensions have become a permanent feature of Africa's political system. A good example of this narrow-mindedness is what sparked up the 'Arab string' which led to the ouster of three powerful Arab leaders. In the word of the great philosopher Aristotle, "no government can stand which is not founded upon justice". That would seem to imply that justice is the surest foundation on which to build a democratic, good a successful government (Etuk, 2003: 111).

An additional confirmation and consequence of failure of governance in Africa is political and bureaucratic corruption. Corruption is a major challenge to governance and development in Africa. It erodes the capacity of the state to deliver services efficiently, provide security and maintain peace, order and social stability. When deep-seated, corruption generates poverty and turns resource-rich countries into low-income, backward societies. Many African countries are trapped in this cycle of corruption, 
poverty and underdevelopment. Corruption is an aspect of poor governance and is defined as the abuse of public office for private gain. Corruption is a complex and multifaceted phenomenon that affects all countries in various degrees, including developed countries. The 2007 Global Integrity Report affirmed that developed countries are still mired in corruption, contrary to the general perception that the wealthier countries are less corrupt because they have reached appreciable levels of development (Global Integrity 2007). Up till recent time, records have shown that a total of about $\$ 380$ billion have been reported stolen by former military and political leaders in few countries in the Sub Saharan African. This amount is also equivalent to all the western aid given to the entire African continent in almost four decades and also equivalent to 300 years of British aid for the continent. The said money is also believed to be about six times the American help given to post-war Europe under the Marshall plan (Blair, 2005:88). Between 1970 and 2000 , the number of Africans subsisting on less than one dollar a day grew from $36 \%$ to more than 70\% (Zack-Williams 2001: 45).

Africa is a continent where there is a veritable environment for corruption to thrive. From 1999 to date, African countries consistently ranked as the most corrupt countries in the world (T I, 2007:17 ). In Africa, corruption is rampant at all levels of government, crippling basic health and education services and other social infrastructures. Good governance is an illusion in a state where corruption is endemic and persistent. The consequence is therefore poverty and is unavoidable. Poverty has been and is still a major problem in Africa. The statistics is incredible despite the political clamour against poverty. Africa harbours one of the largest numbers of poor people in the world. There is gross inability of most Africans to achieve a certain minimal standard of living due to poverty and low purchasing power. Statistics have indicated that $70.8 \%$ of Africans live below the poverty-line of $\$ 1$ a day and up to $92.4 \%$ live below $\$ 2$ a day at year 2003 (The United Nations International Children's Fund, 2003; World Bank, 2006). This is compounded by acute youth unemployment. Currently, various estimates has put unemployment rate in the African continent at between 20 and $65 \%$. Among graduates of tertiary institution, unemployment rate is put at between 50 and $75 \%$. This situation has resulted to general insecurity and high crime rate in several countries. Other symptoms and consequences of bad governance are: incessant religious crisis, persistent ethnic and sectional conflicts, separatist movements and gross social, economic and political instabilities and deepened legitimacy crisis (Etuk, 2003: 112).

Generally speaking, the profile of the African political economy, past and present, is a testimony of a state in search of good, efficient, effective and democratic governance. Politically, people may disagree about the best means of achieving good governance, but they quite agreed that good governance is absolutely imperative for social and economic progress and development (Oburota, 2003). Thus, governance in a political sense is a more complex activity. Secondly, political governance is service oriented. Thus, governance has a lot to do with the allocation of values in the society, which to a large extent is political in nature. Although governance is related to politics, it is conceptually different. However, as a human phenomenon, governance is exercised within a given socio-cultural context and 
belongs to a broader department of politics. While politics is the authoritative allocation of values or who gets what, when and how, governance is the process and mechanisms of allocating the values without jeopardizing the principle of equity, justice and fairness. Indeed, effective democratic forms of governance rely on public participation, accountability and transparency. In most countries today, it is these principles that are used as criteria for distinguishing between good and bad governments.

In this regard, democracy not only prescribes how political power should be acquired but also what to do with it or how it should be exercised (Parekh, 1993). This makes democracy amenable to moral and ethical justifications or judgments. Many scholars who shared this view have associated the tragedy of development in Africa to the absence of democratic rule (Ake, 1996). It is worrisome however, that almost two decades after the "third wave" of democracy has blown across the continent of Africa, Democratisation has not produced the expected result. Rather than engender development and good governance, it has led to anarchy, civil wars, genocide and general political instabilities as have been seen in Rwanda, Democratic Republic of Congo, Kenya, Ivory Coast, Liberia, Uganda, Zimbabwe, Sierra Leone and Nigeria. In Nigeria for instance, Boko Haram, Kidnapping, political assassinations, ethno-religious conflicts, abject poverty, acute youth unemployment and general economic and political decay have been the major dividends of democracy since 1999 when the country returned to civil rule but erroneously flaunted as democracy. All these suggest that there is no automatic connection between democracy and good governance but there is an intrinsic socio-cultural value that enhances democratic performance.

Table 2 : AFRICA'S DEMOCRACY RANKINGS (DEMOCRACY INDEX 2008)

\begin{tabular}{|l|l|l|l|}
\hline RANK & COUNTRY & TYPE OF DEMOCRACY & SCORE \% \\
\hline 1 & Mauritius & Full & 8.04 \\
\hline 2 & South Africa & Flawed & 7.91 \\
\hline 3 & Cape Verde & Flawed & 7.81 \\
\hline 4 & Botswana & Flawed & 7.47 \\
\hline 5 & Namibia & Flawed & 6.48 \\
\hline 6 & Lesotho & Flawed & 6.29 \\
\hline 7 & Benin & Flawed & 6.06 \\
\hline 8 & Mali & Hybrid & 5.87 \\
\hline 9 & Madagascar & Hybrid & 5.57 \\
\hline 10 & Mozambique & Hybrid & 5.49 \\
\hline 11 & Senegal & Hybrid & 5.37 \\
\hline
\end{tabular}


Essien D. Essien

Manifestations of Bad Governance on the Threshold of African Democratic Process and Development

\begin{tabular}{|c|c|c|c|}
\hline 12 & Ghana & Hybrid & $5 \cdot 35$ \\
\hline 13 & Tanzania & Hybrid & 5.28 \\
\hline 14 & Zambia & Hybrid & 5.25 \\
\hline 14 & Liberia & Hybrid & 5.25 \\
\hline 16 & Malawi & Hybrid & 5.13 \\
\hline 17 & Uganda & Hybrid & 5.03 \\
\hline 18 & Kenya & Hybrid & 4.79 \\
\hline 19 & Ethiopia & Hybrid & 4.52 \\
\hline 20 & Burundi & Hybrid & 4.51 \\
\hline 21 & Gambia & Hybrid & 4.19 \\
\hline 22 & Sierra Leone & Hybrid & 4.11 \\
\hline 23 & Mauritania & Authoritarian & 3.91 \\
\hline 24 & Egypt & Authoritarian & 3.89 \\
\hline 25 & Morocco & Authoritarian & 3.88 \\
\hline 26 & Rwanda & Authoritarian & 3.71 \\
\hline 27 & Burkina Faso & Authoritarian & 3.6 \\
\hline 28 & Comoros & Authoritarian & 3.58 \\
\hline 29 & Nigeria & Authoritarian & 3.53 \\
\hline 30 & Cameroon & Authoritarian & 3.46 \\
\hline 31 & Niger & Authoritarian & 3.41 \\
\hline 32 & Angola & Authoritarian & 3.35 \\
\hline 33 & Algeria & Authoritarian & 3.32 \\
\hline 34 & Cote d'Ivoire & Authoritarian & 3.27 \\
\hline 35 & Swaziland & Authoritarian & 3.04 \\
\hline 36 & Gabon & Authoritarian & 3 \\
\hline 37 & Tunisia & Authoritarian & 2.96 \\
\hline 38 & Congo & Authoritarian & 2.94 \\
\hline 39 & Sudan & Authoritarian & 2.81 \\
\hline
\end{tabular}

34 GJDS, Vol. 9, No. 2, October, 2012 


\begin{tabular}{|l|l|l|l|}
\hline 40 & Zimbabwe & Authoritarian & 2.53 \\
\hline 41 & Togo & Authoritarian & 2.43 \\
\hline 42 & Djibouti & Authoritarian & 2.37 \\
\hline 43 & Eritrea & Authoritarian & 2.31 \\
\hline 44 & Democratic Republic of Congo & Authoritarian & 2.28 \\
\hline 45 & Equatorial Guinea & Authoritarian & 2.19 \\
\hline 46 & Guinea & Authoritarian & 2.09 \\
\hline 47 & Libya & Authoritarian & 2 \\
\hline 48 & Central African Republic & Authoritarian & 1.86 \\
\hline 49 & Chad & Authoritarian & 1.52 \\
\hline
\end{tabular}

Source: http://www.eiu.com/index.asp?rf=o

\section{Making Democratic Governance a Platform for African Development}

Governance and democracy are central to Africa's search for social, political and economic regeneration. In recognition of the imperative of good governance for development, African countries, over the last decade, have made remarkable strides and commitments in many directions towards good governance in Africa (Amoako, 2000 : 121). This is however demonstrated by African leaders in their pledged to take joint responsibility to eradicate widespread poverty on the continent and place their countries on a path of sustained economic growth and development as encapsulated in the adoption of the New Partnership for Africa's Development (NEPAD) in 2001. It is pertinent to note that in the last ten years, there is a notable increase in the successes recorded in electoral democracy throughout Africa in relation to the wind rejection and support unpopularity for military and dictatorial regime blowing all over the continent. Similarly, progress in this perspective is exemplified by the adoption of a number of governance initiatives including: the 2001 AU/NEPAD Foundation Document on Conditions for Sustainable Development in Africa; the 2002 Declaration on Democracy, Political, Economic and Corporate Governance; the coming into force of the Protocol to the African Charter on Human and Peoples' Rights in 2004; the 2005 Commission for Africa Report; and the 2007 Potsdam G8 Action Plan for Good Financial Governance in Africa (Kanbur, 2004 :79). It is pertinent to note that the paramouncy of good governance in the achievement of development goals, including the MDGs, has been recognized in the 2001 AU/NEPAD Foundation Document on Conditions for Sustainable Development in Africa.

There is a good reason to support the position that good governance is a sine-qua-non for development in different facet of the society. It involve the creation of the conducive 
socio-economic, legal, political and institutional environments to foster the society's material strength; to free people from the evils of abject poverty, preventable diseases, ignorance, squalor and idleness; to provide the citizenry with the voice to choose those who rule over them, to hold those in power accountable when they do not work for the greater good, to demand transparent structures and to fight down socially regressive policies, and to treat every citizen equal without regard to gender, race, ethnicity, religion, and creed. However, improving good political governance in Africa is of central importance which underlines the basis for sustainable development (Mazrui, 2000 : 99).

Exclusive of any iota of misgiving, the faltering of democratization in Africa may be attributed to the fact that it is not enmeshed so much in the society as it failed in its entirety to pay attention to African realities and peculiarities. It follows therefore that the development of democratic institutions, can only be accomplished by African only when the social foundations have been made somewhat conducive. Indeed, before good governance and democratic reform can actually be accomplished, the (continent's) people must first develop a coherent political structure that has some relevance to their own historical and cultural realities (Lawson, 2000:23). Nevertheless, drawing from the prevailing indicators, the reverse has so far been the case in Africa. This is because currently, the culture of the African people has been largely ignored as if it has no stake or serious implication for the success of development in the continent. There is no mincing word that African culture has fiercely resisted and threatened every project that fails to come to term with it, even as it is acted upon and changed. The existing setting has been problematical due to the lasting heritage of colonialism. For one, the democratic institutions inherited at independence by African political elites were basically western in nature (Elaigwu, 2002:17).

Further, the colonial political culture to which the nationalist leaders were socialized was one characterized by lack of public-spirited restraint in the quest for, and exercise of power (Ake, 1973:358). With this form of socialization largely unchanged, its connotation has been that the actions and activities of the operators of the democratization process have most often created democratic discrepancy. Caught up in this precarious and pathetic situation, there is an urgent need to redress the situation, if democratization must live up to its billings in Africa. It is necessary to reconcile the disconnect between African peculiarities and the inherited institutional as well as socialization structures upon which African democratization experiment, concept of good governance and development strategies are anchored. As long as these structures remain the platform upon which African democratization drives and strategies are fastened up, all developmental drives may appear like putting the cart before the horse and to that extent, turn out be an exercise in futility. There is therefore the need for adaptability in order to make the democratization process agreeable to African realities. 


\section{Ethical Paradigm and Governance}

Ethics is a central element in governance. The work of ethics is to regulate the conduct and activities of the governance and development actors. In the framework of administrative and governance ethics, good governance depends on the extent to which government is perceived and accepted by the general citizenry to be legitimate, committed to improving general public welfare, and responsive to the needs of its citizenry. Ethics therefore sets the platform and principle that provides a framework for good conduct and the kind of action that is good and acceptable. (Lawton, 1998). Against this backdrop, ethical governance denotes administrative measures, procedures and policies that fulfill criteria required for the ethically good or acceptable handling of public affairs, such as in public administration, public health care, education, and social security and other services delivered by government. In the context of governance, ethically good or acceptable behavior is often defined in terms of justice, fairness, equality, and integrity. Thus, ethical governance is just a normative expression and not a purely descriptive one. The concept of ethical governance also implies a value assessment and is thus value-laden. However, the use of the adjective 'ethical' does not possess automatic guarantee for the true ethical goodness, such as the availability of justice, fairness, equality, integrity of governance. Thus, the term 'ethical governance' should be used for actual systems of governance only when the appraisal is based on a critical and unbiased evaluation of their goals, objective and policy thrust. Such evaluation requires invoking normative premises like commands and prohibitions. For example, 'Governance should be equal and impartial', 'Civil servants and service providers ought to keep their promises and be true to their word', and 'Authorities should take good care of public affairs' (Dobel, 1999). Consequently, ethical governance, as a normative notion, denotes the characteristics or virtues of ethically good civil servants. At the same time, it denotes the criteria based on which the ethical quality of governance is assessed. These criteria involve, for example, the integrity, equality, and justness of government servants and of their administrative activity. The ethical quality of governance can either be good or bad. If it is good, it shows that governance is ethical or conforms to ethical requirements. On the other hand, if it is bad, it indicates that governance is unethical or breaks ethical standards. One common way of explaining these characterizations is to say that in good governance, the actors and authorities follow the ethical and other norms, commands and prohibitions they are obligated to follow concerning their actions. Bad governance violates these norms. In simple terms therefore, the ethicality of governance is expressed in terms of rule observation. Thus, the concept of governance ethicality in Africa should involve an evaluative feature that is often conceptualized as obedience to rules. The question of the abuse of authority and violation of human rights by the courts, the police and other law enforcement agencies figured prominently the ethical deficiency of governance actors in some areas of Africa.

Using consequentialism as an ethical doctrine, Citizens in all societies general prefer an approach in which authorities listen to them, take efficient care of their issues and problems, and appreciate them as individuals. This basically demands from governance actors behaviours which has the best consequences. It further presupposes that the core 
ethical values of justice, openness, trust, integrity, responsibility and accountability which underlie good democratic governance should be inculcated by the major players in governance. In Africa, governance and administrative ethics as well as integrity violations have been the subject of considerable scholarly study and research impinging on governance (Jackson, 1997). Integrity violations challenge the functioning of any democracy in the threshold of development anywhere in the world. It varies from corruption to unethical social behavior prevalent in all facet of our governance structure. Integrity violations are divided to cover corruption, fraud and theft of organizational resources, conflicts of interest, the abuse and manipulation of information, discriminatory treatment and the waste of organizational resources. Two fundamental types of integrity violations have been identified. They include, bribes, theft and fraud which belong to the serious forms of corruption, and the remaining integrity violations are typical forms of maladministration, bad governance, etc. It is clear that citizens' views concerning corruption are one of the main assessment tools concerning governance when estimating its breadth and injuriousness. It is incontrovertible that Corruption anywhere it exists always has a national character and constitutes a major impediment towards good governance and development in Africa.

\section{Conclusion}

The modern history of Africa is a troubled one characterized by struggles to reverse the trend of political despair and disappointment, which hitherto typify political life in Africa. Africa's record in improving governance remains, at best, a mix bag. Africa contains $15 \%$ of world population, occupies $20 \%$ of its landmass, but accounts for only $2 \%$ of its global output. Regrettably, Africa harbours the highest stock of the world's poorest people. In this paper, we have attempted to explore the concepts of good governance, democratization and development with a view to separating the ambivalence contiguous to them, particularly as regards their relationship. It is evident in the study that the quality of life for most Africans, has either not improved or has done so marginally since the inception of the OAU in 1963.

Although a lot of hopes and expectations are provided in the current process of democratic modification and its capacity to engineer good governance, the possible outcome of the process remains uncertain and open to speculation. In Africa, just like any other region of the world, the indicators and cost of bad governance are corruption, injustices, inequity, integration crisis, ethno-religious feuds and a host of others (Joseph, 2002 : 33). Corruption has generated an unthinkable level of poverty in Africa and has further destroyed good governance. This article argues that improving accountability relationships is an effective strategy for developing capacity for good governance and development. Therefore, effective accountability mechanisms such as reliable and legitimate ground rules or constitution, effective judiciary system, access to information and awareness, opening of channels and avenues for participation, civic engagement and civil societies monitoring induce public sector organizations to remain relevant 
and responsive to the needs and demands of the groups and individuals they serve. The study establishes that despite its enormous resources and huge potentialities, Africa remains grossly undeveloped because non adherence to positive ethical principles such as honesty, justice, accountability, and transparency which are exceptional drivers of good governance and development. Against this backdrop, political instability, abject poverty, acute youth unemployment, heightened crime rate, poor health provision and widespread malnourishment have been the main features of Africa's political economy. This study therefore concludes that the problem of development in Africa is a problem of governance viewed from the perspective of disgusting violation of ethical principles of integrity and trust which disfigure fair and equitable allocation of resources for the achievement and promotion of the common good.

\section{References}

Ake, C. (1996). Democracy and Development in Africa, Washington DC: The Booklings Institution.

Amoako, K. Y. (2000). Perspectives on Africa's Development. New York: United Nations.

Anyanwu, A. (1998). "Governance and Africa Politics", in C. E. Emezi and C. A. Ndoh (eds.) African Politics. Owerri: Achugo Publications.

Ayoade, J.A.A. (1986) “The African Search for Democracy: Hopes and Reality." In Ronen, D. (ed). Democracy and Pluralism in Africa, Boulder, Colorado: Lynne Rienner.

Besancon, M. (2003). "Good governance rankings: the art of measurement." World Peace Foundation Reports Online, No. 36, Cambridge, Massachusetts [online].Available:http://bcsia.ksg.harvard.edu/BCSIAcontent/documents WPF36Governance.pdf

Cheema, G.S. (2005). Building democratic institutions : governance reform in developing Countries. New York, Kumarian Press Inc.

Conable, B. (1991). “Africa's Development and Destiny." Address to the 27th Session of the Organization of African Unity, Assembly of Heads of State and Government, Abuja, Nigeria, Washington: World Bank (June).

Degefe, B. (1990). “The African Crisis: Some Suggestions for Its Mitigation”, In African Governance in the 19gos. Atlanta, Georgia: Carter Center.

Diamond, L. (1987). Prospects for Democratic Development in Africa , Stanford: Hover Institution's Essay in Public Policy.

Dobel, P. J. (1999). Public Integrity. Baltimore and London: The Johns Hopkins University Press. 
Elaigwu, J.I. (2002). “Democracy, Transparency and Accountability in Nigeria,” Newswatch Annual Lecture, Lagos. Newswatch, vol. 6, No. 2, February 18, 2002.

Ekeh, Peter (1975). "Colonialism and the Two Publics in Africa." Comparative Studies in History and Society 17(1): 91-112.

Etuk, U (2003). Democratization and Development in Africa. Ibadan: Spectrum Books Ltd.

Ihonvbere, J. (1996). "On the Threshold of another False Start? A Critical Evaluation of Movements in Africa," Journal of Asian and African Studies, Vol. 34, Nos. 1-2.,pp. 119.

Jackson, T. (1997). Ethical Beliefs and Management Behavior: A Cross-Cultural Comparison. Journal of Business Ethics 16 (11), 1163-1173.

Joseph, R. (2002). Smart Partnerships for African Development: A New Strategic Framework. Washington, DC: United States Institute of Peace, pp. 90-91.

Kanbur, R. (2004). The African Peer Review Mechanism (APRM): An Assessment of Concept and Design [online]. Available: http://www.people.cornell.edu/pages/sk145 (accessed 24 February 2007).

Lane, J.E. and Ersson, S. (1997). Comparative Political Economy: A Development Approach. London and Washington: Pinter ( $2^{\text {nd }}$ Edition).

Lawson, (1991). "External democracy Promotion in Africa: Another False Start?, Commonwealth and Comparative Politics, Vol.37, No.1 (March).

Lawton, A. (1998). Ethical Management for the Public Services. Buckingham, UK: Open University Press.

Luckham, R. ( 1995). "Dilemmas of Military Disengagement and Democratization in Africa.” IDS Bulletin, 26(2).

Madhav, G (2007). "Election or Selection? Human Rights Abuse and Threats to Free and Fair Elections in Nigeria." Report of the Committee on Good Governance, Human Rights Watch, July [online]. Available: http://hrw.org/backgrounder/africa/nigeriao407/ index.htm. Accessed, February 2012.

Mazrui, A. (2000). "Nigeria's Search for Good Governance and National Development: Dilemmas of Policy and Leadership." In Lame, I.Y. and Dabin, H. (eds). Democracy, Good Governance and National Development in Nigeria: Actualizing the People's Mandate, (Proceedings of a National Seminar Organized by PDP).Ibadan, Nigeria: Spectrum Books.

Nunnenkamp, P. (1995), "What Donors Mean by Good Governance: Heroic Ends, Limited Means and Traditional Dilemmas of Development Cooperation.” IDS Bulletin. 26 (2). 
Nzongola-Ntalaja, G. (2002). "UNDP role in promoting good governance", Seminar for the International Guests at the Congress of the Labour Party of Norway, Oslo [online]. Available: http://www.undp.org/oslocentre/pub.htm

Obadan, M. I. (1998). “The State, Leadership, Governance and Economic Development.” A Presidential Address Delivered at the Annual Conference of the Nigerian Economic Society, Kano. The National Centre for Economic Management and Administration (NCEMA).

Oburota, A. (2003). “Governance as a Source of Social Violence in Africa." In Oguejiofor J. Obi (Ed.). Philosophy, Democracy and Responsible Governance in Africa. (388 - 398). New Brunswick and London, Transaction Publishers.

Ogwu, J. (2002). "The African Union and the Challenge of Development in the 21st Century." Public Lecture Series No. 1. Department of Political Science, University of Ilorin, Nigeria.

Osaghae, E.E. (1999) "Democratization in Africa: Faultering Prospects, New Hopes." Journal of Contemporary African Studies, Vol 17, No.1 January.

Ottaway, M. (1995). “Democratization in Collapsed States." In Zartman, I.W. (ed). Collapse States: The Disintegration and Restoration of legitimate Authority. (240 - 244). London: Lynne Rienner.

Owolabi, K. A. (2003). "Can the Past Salvage the Future? Indigenous Democracy and the Quest for Sustainable Democratic Governance in Africa." In Oguejiofor J Obi (Ed.). Philosophy, Democracy and Responsible Governance in Africa. (431 - 444), New Brunswick and London, Transaction Publishers.

Parekh, B. (1993). "The Cultural Particularity of Liberal Democracy." In David Held (ed.) Prospects for Democracy: North, South, East, West. Cambridge: Polity Press.

Plumptre, T., (2004). “What is governance?", Institute on Governance [online].Available: http://www.iog.ca/page.asp?pageID=3\&htmlarea=home, Accessed, March2012.

Rotberg R.I. (2005). "Strengthening governance: ranking countries would help." The Washington Quarterly 28:1 (2004-05): 71-81[online]. Available: http://bcsia.ksg. harvard.edu/perso cfm?order_by=name\&program=WPF\&ln=full\&item_id=242. Date Accessed: April 2011

Potter, D. (2000). “Democratiza tion, Good Governance and Development." In Allen, T. and Thomas, A. (eds). Poverty and development into the 21st Century. UK: The Open University and Oxford University Press.

Todaro, M.P. (1989). Economic Development in the Third World. 4th edition. New York: Longman. 
Transparency International (2006). Global Integrity Report [online]. Available: http:// www.globalintegrity.org

Transparency International (TI) (2007). http://www.transparency.org. Accessed: 5/5/2012.

Turok, B. ( 1987). Africa: What Can Be Done? London; Zed Books.

United Nations (2000). "Millennium Development Goals."[online]. Available: http://www. un.org/millenniumgoals, Date Accessed: June, 2012.

Van de Walle S.(2005). "Measuring Bureaucratic Quality in Governance Indicators." Working Paper presented to the Instituut voor de Overheid, Kat holieke Universiteit, Leuven, Belgium (unpublished).

World Bank, (2001). World Development Report 2000/2001: Attacking Poverty Oxford: Oxford University Publishers.

World Bank, (2006). World Development Report 2006: Equity and Development. Oxford: Oxford University Press.

World Bank (2007). "Strengthening World Bank Group Engagement on Governance and Anticorruption"[online]. Available: http://www.worldbank.org/html/ extdr/comments/governancefeedback /gacpaper-03212007.pdf. Date Accessed: 24/2/2008. 